\title{
Residents' Assessment of Media Role in Environmental Health Education in Onitsha Urban, Anambra State, Nigeria
}

\author{
Nwankwo, Ignatius Uche (PhD) \\ Department of Sociology/ Anthropology, Nnamdi Azikiwe University, Awka.
}

\begin{abstract}
This empirical study examined residents' assessment of media role in environmental health education in Onitsha Urban, a metropolitan area with rapidly growing population. One hundred and ninety five respondents were selected for the study through a combination of multi-stage and simple random sampling processes. Seven research questions and one hypothesis were formulated. Questionnaire and in-depth interview complemented each other as instruments for data collection. The study found that residents considered refuse accumulation as the major environmental health challenge encountered in the area. Respondents also assessed the level of environmental health education or awareness in the area as very low, as the media played very minimal role in that regards. Chi-square test of the hypothesis showed that education has significant relationship with perception of environmental health problems where those with low education are less bothered and unlikely to take proactive actions to salvage the situation. On the other hand, logistic regression analysis predicted that older respondents are more likely to be positively disposed to their environmental health responsibilities than younger ones. It was recommended that public enlightenment on environmental health be strengthened through the media, to prevent further decay of the environment at Onitsha Urban, Anambra state, Nigeria.
\end{abstract}

Keywords: Environmental health, Health, Media, Pollution, Residents'assessment, Solid wastes

\section{INTRODUCTION}

Health, defined by World Health Organization (WHO, 2006) as a state of complete physical, mental and social well being and not merely the absence of disease or infirmity is an attribute relevant to community development. Healthcare service is one of the most important services provided by the government in every country of the world. When most members of a community are regularly ill and cannot promptly access affordable health services, it affects the ability of society to develop at the anticipated pace. This is because sound health condition enables individuals to make optimum contributions to society by effectively discharging their habitual or health roles.

The interrelationship between man's 'environment' and his state of health has long been recognized by scholars (see Mogbo, 2004; Obionu, 2011). The concept of environment refers to the aggregate of the physical and biological entities or locations external to man and supporting his existence. Man's environment constitutes his surroundings like water, land, plants and animals around him etc. On the other hand, 'environmental health' refers to the control of all those factors in mans environment which exercise or may exercise a deleterious effect on his mental, physical or social well being. Environmental health encourages assessment and control of those external factors that can potentially affect health. Its core focus is towards preventing diseases and creating health - support environments. According to the World Health Organization (WHO 1992), environmental health enquires into man's state of health, as determined or influenced by factors in the environment. It's attention is on both the direct pathological effects of various chemical, physical and biological agents as well as the effects on health of the physical and social environment which includes housing, urban development, land use and transportation, industry and agriculture.

In relating environmental quality to the state of health of man, Babanyara , Usman \& Saleh (2010) noted that filthy and unkempt environment poses tremendous threat to mankind. According to them, such environment breeds disease germs that attack man. On their part, the Environmental Health Officers Association of Nigeria (EHOAN, 2007) decried the increasing magnitude of environmental health problems facing rural and urban towns in Nigeria. She outlined some of the problems to include poor sanitary conditions, pollution of land, air and water through contamination by biological, 
chemical and physical agents that arise from natural events, human activity or the interaction of the two. Other environmental health problems identified by EHOAN (2007) include inadequate solid waste disposal, effluent discharge, rapid and unplanned urbanization, mining hazards, increasing use of chemical fertilizers and insecticides, poor meat and food hygiene, emission of green house gases and the depletion of the ozone layer. Others are climate change, flood disasters, deforestation, drought and desertification etc. She (EHOAN, 2007) further observed that many diseases that cause high incidence of morbidity and mortality in Nigeria are environment related. She also lamented that in Nigeria, environmental health problems in urban centers are compounded by population growth, rapid industrialization and massive level of ignorance (poor environmental health education /awareness). The prevailing excruciating poverty of many urban dwellers contributes to their not taking proactive actions to safeguard their environment.

Above all, the Centre for Public Health, University of Liverpool (2009) has warned that mankind's activities within the environment in quest for development have resulted in a continuous and serious degradation of the ecosystem, thus posing serious threat to man's present and future living. According to Obianyo (2004), human beings use the environment in three basic ways:

As a resource bank - the environment supplies them with raw materials needed to maintain their existence and their social and technological structures;

As a habitat - people require more space per individual than any other species; and

As sink for wastes - human beings produce more waste than other species. Unwise use of the natural environment due to ignorance, poverty, over population and greed amongst others led to its degradation.

Nonetheless, issues of unwise use of the environment due to ignorance could be remarkably attended to through media narratives and programming. The media or mass communication industry in the context of this paper is conceived as the process of transmitting information, ideas, and attitudes simultaneously to many people usually through a machine. The term also describes the various means by which individuals and social collectives relay information through mass media to large segments of the population at the same time. Mass communication options considered relevant to environmental health education include newspaper and magazine publishing, radio, television and film or cinema, and the social media. All of these are generally used for dissemination of important information, education of the people, entertainment, advertising and marketing. The focus of this paper is however on media role in health information dissemination with emphasis on environmental health education, sensitization and awareness creation.

Okafor, Nwankwo, Oli, Oguamanam (2016) defined health information dissemination as all processes aimed at educating, enlightening, informing or transmitting to the people, health issues that are of benefit to them. It is intended to improve health awareness or information at their disposal such that they can live much healthier lives, shaped by informed choices they make. Such choices are derived or anchored on correct health information at their disposal. The concepts of health education and health information dissemination are thus considered as interchangeable terms with complimentary meanings and objectives.

It is against the backdrop of aforementioned issues and uses of the environment which have implications defined by time, space, quality of use, and level of socio-economic development amongst others, that this study was undertaken to ascertain the public assessment of media role in environmental health education (aimed at countering environmental health problems that may have arisen from various uses of the environment) at Onitsha Urban, Anambra State, Nigeria.

\section{Statement of the Problem}

This study is located in Onitsha Urban, the commercial nerve centre of Anambra State of Nigeria. In addition to aforementioned environmental health problems applicable to other towns in Nigeria, the infrastructural development and social changes in terms of influx of migrants taking place at Onitsha appears to have set in motion negative consequences such as slums, inadequate urban infrastructure, and lack of basic services due to pressures from increase in population. Others are poor sanitation and refuse disposal system, discharge of sewage water on roads, dirty gutters/drainages, uncontrolled street trading, unsanitary habits of residents, congested transport system, and serious environmental pollution (Obianyo, 2004). All these conditions are hazardous for human living.

According to Dike (1985), the rapid growth of Onitsha, the lack of or non adherence to a master plan, the failure to maintain old and newly built infrastructure and the inefficiency of the local government 
have all contributed to its deterioration. It's noisy, dirty streets, littered with uncollected and decomposing garbage, have become regular aspects of people's lives in the area. This assertion by Dike aptly describe Onitsha environmental situation.

Furthermore, Nwankwo (2014) observes that there seems to be a growing tendency among scholars to describe Onitsha as a 'dirty town' and its residents as 'indifferent or negatively disposed' (meaning not committed/interested, unwilling to participate or take proactive measures) on environmental health matters. For instance, EHOAN (2007) decried that although Onitsha is among the towns in Nigeria with very poor solid waste disposal system and experience heavy pollution of land, air and water, the residents seem to be non challant about the situation.

The attitude of residents cannot be unconnected with their level of understanding of environmental health problems of the area and the impact they may impose to their health. This means the way they understand and interpret environmental health problems of the area in terms of causes, effects and required mitigating measures.

Such understanding are usually shaped by the media narratives and other social factors which Nwankwo (2006) specifically discussed like level of educational attainment, occupation, income size, belief system, peer pressure, and varied socialization experiences among others. According to him, these factors constitute important variables related to both health outcomes and nature of individual response to environmental cleanliness and sustainability. Similarly, Erinosho and Oke (2004) had noted earlier that in Nigeria, the social and cultural factors of the environment are crucial in the definition of health status of the people.

Regrettably, low awareness about available environmental health programmes, services and interventions (which give rise to low level of community participation and patronage) characterize the health sector in much of Nigeria's territorial space. For instance, Metiboba [5] argued that limited knowledge or low awareness about health reform project in rural areas and even among many urban dwellers is a disservice to the success of health reform efforts in Nigeria. He advocated that a comprehensive public enlightenment and healthcare coverage of entire Nigerian society is crucial. The field of environmental health is in daring need of such public enlightenment at Onitsha Urban, Anambra State, Nigeria.

Also worrisome is the fact that the response of socio-cultural institutions like age groups and women associations to environmental health problems has been largely defined in terms of exclusion. A lot of expectation appears to be placed on government agencies alone to attend to environmental health needs of the town without fully exploring other local options. According to Nwankwo (2006), the role of age sets and women groups in environmental sanitation in traditional Igbo society was tremendous but now neglected in many urban communities. On his part, Obianyo (2006) was worried that 'positive attitude or disposition to environmental health responsibilities' tends to be fading away among the youths who now find it difficult to take collective actions to address the embarrassing refuse problems of Onitsha urban town.

The above problem list underscores the important role of media in environmental health education to positively affect or strengthen interventions like appropriate individual behavioural response, community response, proper waste management options, and physical planning services, observance of legal and institutional frameworks relevant to environmental health standards maintenance, infrastructure development and consolidation of urban safety plans among others. Most importantly, the highlighted problems justify the interrogation of public assessment of extent of media involvement and discharge of her role in environmental health education of residents of Onitsha Urban with a view to ensure a healthy environment supportive of healthy living where environmental health problems are minimal or nonexistent of the area.

\section{RESEARCH QUESTIONS}

The following questions guided the study:

- What do residents of Onitsha Urban in Anambra State, Nigeria consider as major environmental health challenges encountered in their area?

- What factors give rise to environmental health challenges in Onitsha Urban of Anambra State, Nigeria? 
- How do residents of Onitsha Urban rate their level of awareness or enlightenment about environmental health issues in their area?

- What major roles or activities do the media discharge/undertake relevant to environmental health education in Onitsha Urban?

- How do residents of Onitsha Urban of Anambra State, Nigeria assess media roles or activities relevant to environmental health education in terms of their effectiveness or impact?

- What are the perceived obstacles confronting media institutions in discharging environmental health education roles in Onitsha Urban, Anambra state of Nigeria?

- What measures should be put in place to step up media roles and ensure safe environmental health standards at Onitsha Urban in Anambra State?

\section{HYPOTHESIS}

The under listed hypothesis was proposed for the study;

"There is a significant relationship between one's level of educational attainment of Onitsha Urban Residents and their perception of major environmental health challenges of the area'.

\section{Theoretical Thrust}

This study is anchored on the human ecological theory which focuses on the relationship between people and their environment. According to Nnatu (2010), ecologists examine how people influence their environment and how the physical environment shape people's lives.

In his application of the human ecological perspective to social discourse, Sociologist Riley Dunlap cited in Mooney, Knox \& Schacht (2000) suggests that the natural environment serves three basic functions for humans, as it does for other animal species. They are: (a) the environment provides the resources essential for life; (b) the environment serves as a waste repository; (c) the environment "houses" human species:

In facing the environmental challenges of urban areas, government, policy makers and environmentalists must determine how to meet society's pressing needs like food, clothing and shelter while at the same time preserving the environment as a source of resources, a waste repository, and our home. The way man handles the environment determines the level of effect it has on him or the environmental health problems that will emerge. When individuals harness the natural resources unlawfully or dump refuse indiscriminately, the aftermath is always very disastrous.

\section{AREA OF THE StUdY}

The area of the study is Onitsha Urban in Anambra state of Nigeria which occupies the northern most point of the popular River Niger. The neighbouring towns of Onitsha include Asaba, Nkwelle, Obosi, Aboh, Ogidi among others. Onitsha Urban is comprised of two council areas (Onitsha North and Onitsha South Council Areas). Onitsha North is made up of nine quarters (Bosah, 2000) with the South about the same size.

Onitsha's latitude is 6, $1667\left(610^{\prime} 0.12^{\prime \prime} \mathrm{N}\right)$, longitude is 6, $7833\left(646^{\prime} 59.988^{\prime \prime}\right.$ E) and altitude of $59 \mathrm{~m}$. (UN Habitat, 2009). The people of Onitsha were said to have migrated from Benin in present Edo State with whom they share several cultural traits. The traditional ruler of Onitsha is addressed as "Obi". The people of Onitsha are blessed with rich cultural practices like the popular 'Ofala' rites. Onitsha has more than five media houses,

According to Bosah (2000), in the early days of their settlement, the indigenes of Onitsha lived on foods like: cassava, native beans fish and fruits; they had fishing and trading on foodstuff as their traditional occupation. Civilization brought a decline in the fishing occupation but encouraged large scale trading. With regards to trading today, Onitsha main market is acclaimed as the largest market in West Africa.

\section{INSTRUMENTS AND METHODS}

A cross-sectional survey design was adopted for the study. The 2006 National Population Census figure for Onitsha North Local Government Area was 125, 918, made up of 61, 588 males and 64, 330 females. However, the target population used for this study were adults aged 18years and above whose population was estimated to about 62,959 (Bosah, 2000).

A sample size of 195 study participants were administered with questionnaire, while five (5) respondents who are environmental health service providers were interviewed to complement 
quantitative data. This sample size was large enough and accommodated chi-square and other inferential statistics employed for data analysis. The multi-stage and simple random sampling techniques, suitable for large-scale surveys were adopted in the selection of study participants. However, the five (5) respondents interviewed were purposively drawn. These were three (3) officials of Anambra State Environmental Protection Agency (Onitsha Zonal Office) and two (2) officers of the Environmental Health Unit of Onitsha North LGA.

The questionnaire contained closed ended questions while the interview schedule had open ended items. Both instruments were pre tested in Awka for reliability after validation by senior academics that thoroughly checked their contents vis-à-vis their appropriateness to meet research objectives.

The researcher and two assistants administered the questionnaire made up of 23 closed ended items on self administered basis. However, other administration option was adopted for few respondents who cannot read and write. In both instances, researcher related biases in questionnaire administration were avoided by adhering strictly to established sampling procedure and by withholding leading comments/clues to any question on the part of the researcher.

The interview was conducted with an interview guide that contained 10 open ended items. It was held at respondents' offices with the help of two research assistants using tape recorder and field notebook for recording.

The Statistical Package for Social Sciences (SPSS) was used to process the data. Data collected was analyzed at three levels. At the univariate level, simple percentages and frequency distribution tables were used. At the bivariate level, the stated hypothesis was tested with chi-square $\left(\mathrm{x}^{2}\right)$ test statistic which measures association and frequency. At the multi-variate level, logistic regression analysis was used to predict 'disposition to environmental health responsibilities' across socio-demographic attributes of respondents. . The qualitative data was analyzed using manual content analysis technique involving collation, transcription and interpretation. Relevant areas of qualitative data were used to support the quantitative and were sometimes reported verbatim

\section{Data Presentation And Analysis}

Table1. Personal Data of Respondents.

\begin{tabular}{|c|c|c|c|}
\hline \multirow[t]{4}{*}{ Distribution of respondents by sex } & Variables & Frequency & Percent \\
\hline & Male & 47 & 24.1 \\
\hline & Female & 148 & 75.9 \\
\hline & Total & 195 & 100.0 \\
\hline \multirow[t]{8}{*}{ Distribution of respondents by age } & $20-29$ & 100 & 51.3 \\
\hline & $30-39$ & 54 & 27.7 \\
\hline & $40-49$ & 28 & 14.4 \\
\hline & $50-59$ & 8 & 4.1 \\
\hline & $60-69$ & 3 & 1.5 \\
\hline & Total & 193 & 99.0 \\
\hline & No Response & 2 & 1.0 \\
\hline & Total & 195 & 100.0 \\
\hline \multirow[t]{4}{*}{ Distribution of respondents by marital status } & Ever Married & 108 & 55.4 \\
\hline & Single & 84 & 43.1 \\
\hline & Widow/widower & 3 & 1.5 \\
\hline & Total & 195 & 100.0 \\
\hline \multirow[t]{3}{*}{ Distribution of respondents by religious affiliation } & Christianity & 193 & 99.0 \\
\hline & Islamic & 2 & 1.0 \\
\hline & Total & 195 & 100.0 \\
\hline \multirow{10}{*}{$\begin{array}{l}\text { Distribution of respondents by level of education } \\
\text { attained }\end{array}$} & No formal ed. & 4 & 2.1 \\
\hline & FSLC & 5 & 2.6 \\
\hline & SSCE & 52 & 26.7 \\
\hline & B.Sc. & 112 & 57.4 \\
\hline & Ph.D. & 13 & 6.7 \\
\hline & NCE & 5 & 2.6 \\
\hline & M.Sc & 4 & 2.1 \\
\hline & Total & 195 & 99.0 \\
\hline & No Response & 2 & 1.0 \\
\hline & Total & 195 & 100.0 \\
\hline \multirow[t]{7}{*}{ Distribution of respondents by occupation } & Self employed & 14 & 7.2 \\
\hline & Civil/Public Servants & 8 & 4.1 \\
\hline & Trader & 105 & 53.8 \\
\hline & Unemployed & 11 & 5.6 \\
\hline & Artisan & 5 & 2.6 \\
\hline & Apprentice/Students. & 52 & 26.7 \\
\hline & Total & 195 & 100.0 \\
\hline
\end{tabular}


Table 1 shows that $47(24.1 \%)$ of the respondents were males while $148(75.9 \%)$ of them were females. This implies that majority of the respondents in this study were females. Also, about $100(51.3 \%)$ of the respondents in this study, constituting the majority were youths aged 20-29. However, the mean age of respondents was 32 years old. Other details of demographic data of respondents were as shown on Table 1 above.

\section{ANALYSIS OF RESEARCH QUESTIONS}

Seven (7) research questions were asked to guide this study. These questions are re-stated and analyzed accordingly.

\subsection{Research Question 1:}

What do residents of Onitsha Urban in Anambra State, Nigeria consider as major environmental health challenges encountered in their area? The findings are presented in Table 2 below.

Table 2: Distribution of Respondents by their opinion on major environmental health challenges encountered at Onitsha Urban

\begin{tabular}{|l|l|l|}
\hline \multicolumn{1}{|c|}{ Responses } & \multicolumn{1}{c|}{ Frequency } & \multicolumn{1}{c|}{ Percent } \\
\hline Water Pollution & 19 & 9.7 \\
\hline Air Pollution & 22 & 11.3 \\
\hline Noise & 56 & 28.7 \\
\hline Refuse accumulation & 98 & 50.1 \\
\hline Total & $\mathbf{1 9 5}$ & $\mathbf{1 0 0 . 0}$ \\
\hline
\end{tabular}

Table 2 shows that $98(50.1 \%)$ of the respondents who constitute the majority, saw refuse accumulation as the major environmental health problem faced by residents of Onitsha Urban. However, 56 (28.7\%) of the respondents felt that noise was the major problem, while $22(11.3 \%)$ and $19(9.7 \%)$ pointed towards air and water pollution respectively

\subsection{Research Question 2:}

What factors give rise to environmental health challenges in Onitsha Urban of Anambra State, Nigeria? The findings are shown in tables 3.

Table3. Distribution of Respondents by their opinion about the most important factor that gives rise to environmental health challenges in Onitsha Urban

\begin{tabular}{|l|l|l|}
\hline Responses & Frequency & Percent \\
\hline Over population & 16 & 8.2 \\
\hline Nonchalant attitude of residents & 32 & 16.4 \\
\hline Ignorance/poor environmental health awareness and consciousness & 58 & 29.7 \\
\hline Poor work delivery of environmental health agencies & 25 & 12.8 \\
\hline Lack of tree planting & 9 & 4.6 \\
\hline Poor refuse disposal system & 34 & 17.2 \\
\hline Fumes and smoke & 3 & 1.5 \\
\hline Street trading & 18 & 9.2 \\
\hline Total & $\mathbf{1 9 5}$ & $\mathbf{1 0 0}$ \\
\hline
\end{tabular}

Table 3 shows that the majority of the respondents agree that ignorance or poor environmental health awareness (and consciousness) constitute the most important factor that gives rise to environmental health problems in the view of residents. The next important factor is poor work delivery of environmental health agencies.

The responses presented in table 3 were further buttressed by findings from in-depth interview. Most of the interviewees were of the view that poor management of refuse and lack of facilities like pay loaders give rise to environmental health problems. An interviewee from Environmental Health Unit of Onitsha North Council Area stated that 'Onitsha North Local Government has no functional Tipper Lorries or Pay loaders for evacuation of refuse from designated dumps. Furthermore, fund for such services is lean and often not released promptly'. Another interviewee from ANSEPA office at Onitsha lamented that 'lack improper disposal of waste into drainage systems give Onitsha one of her greatest environmental health challenges'. 
Residents' Assessment of Media Role in Environmental Health Education in Onitsha Urban, Anambra State, Nigeria

\subsection{Research Question 3:}

How do residents of Onitsha Urban rate their level of awareness or enlightenment about environmental health issues in their area? The findings are shown in tables 4, and 5.

Table 4: Distribution of Respondents by their view on whether enlightenment of Onitsha Urban residents on environmental health issues/ problems of the area is adequate

\begin{tabular}{|l|l|l|}
\hline \multicolumn{1}{|c|}{ Responses } & \multicolumn{1}{c|}{ Frequency } & \multicolumn{1}{c|}{ Percent } \\
\hline Not adequate & 173 & 88.7 \\
\hline Adequate & 22 & 11.3 \\
\hline Total & $\mathbf{1 9 5}$ & $\mathbf{1 0 0 . 0}$ \\
\hline
\end{tabular}

Table 4 shows that $173(88.7 \%$ ) of the respondents believe that there is inadequate enlightenment of residents which contributes to environmental health problems at Onitsha. $\mathrm{H}$ Information gathered from the in-depth interview also suggests that ignorance contributes to their seemingly negative disposition towards environmental health. An interviewee from Environmental Health Unit of Onitsha North LGA observed that ignorance about environmental health matters and the link between disease and environment is high in Onitsha. People are more interested in making money in total disregard to the quality of their environment'

Table 5: Distribution of Respondents by their attendance of environmental health awareness and enlightenment seminar in their community to update knowledge

\begin{tabular}{|l|l|l|}
\hline \multicolumn{1}{|c|}{ Responses } & \multicolumn{1}{c|}{ Frequency } & \multicolumn{1}{c|}{ Percent } \\
\hline Yes & 60 & 30.8 \\
\hline No & 134 & 68.7 \\
\hline Total & 194 & 99.5 \\
\hline No Response & 1 & 5 \\
\hline Total & $\mathbf{1 9 5}$ & $\mathbf{1 0 0 . 0}$ \\
\hline
\end{tabular}

Table 5 shows that only 60(30.8\%) of the respondents have attended or benefited from environmental health awareness lecture/seminar in their communities. Most respondents (134 or 68.7\%) have never attended or benefited from such lecture/seminar in their community. This finding has implications for the level of commitment and knowledge of individuals.

\subsection{Research Question 4:}

What major roles or activities do the media discharge/undertake in Onitsha Urban relevant to environmental health education?

Table6. Distribution of Respondents by their view on whether the mass media can help to provide environmental health education in their area?

\begin{tabular}{|l|l|l|}
\hline \multicolumn{1}{|c|}{ Responses } & \multicolumn{1}{|c|}{ Frequency } & \multicolumn{1}{c|}{ Percent } \\
\hline Yes & 188 & 96.4 \\
\hline No & 7 & 3.6 \\
\hline Total & $\mathbf{1 9 5}$ & $\mathbf{1 0 0 . 0}$ \\
\hline
\end{tabular}

Table6 shows that $188(96.4 \%)$ of the respondents which is the majority opined that the mass media can help to provide environmental health education, only 7(3.6\%) of the respondents do not have the same opinion.

Table7. Respondents opinion on activities the media could use or are using to promote environmental health education in Onitsha Urban?

\begin{tabular}{|l|c|c|}
\hline \multicolumn{1}{|c|}{ Responses } & Frequency & Percent \\
\hline News items & 25 & 12.3 \\
\hline Documentaries' & 2 & 1.0 \\
\hline Advertisements/Jingles & 71 & 36.4 \\
\hline Audience participation programmes & 2 & 1.0 \\
\hline All of the above & 96 & 49.2 \\
\hline Total & $\mathbf{1 9 5}$ & $\mathbf{1 0 0 . 0}$ \\
\hline
\end{tabular}

Table 7 shows that $96(42.2 \%)$ of the respondents believe that media outfits could use all the listed activities to promote environmental health education in Onitsha Urban 


\subsection{Research Question 5:}

How do residents of Onitsha Urban of Anambra State, Nigeria assess media roles or activities relevant to environmental health education in terms of their effectiveness or impact? The findings are shown in tables 8 and 9 .

Table8. Distribution of respondents by their view on the extent that the media participate or undertake activities that promote both environmental health education at Onitsha Urban?

\begin{tabular}{|l|l|l|}
\hline \multicolumn{1}{|c|}{ Responses } & \multicolumn{1}{c|}{ Frequency } & Percent \\
\hline They participate actively & 26 & 13.3 \\
\hline They show minimal participation & 95 & 48.2 \\
\hline They do not participate at all & 70 & 35.4 \\
\hline Undecided & 2 & 1.0 \\
\hline I don't know & 3 & 3.0 \\
\hline Total & $\mathbf{1 9 5}$ & $\mathbf{1 0 0 . 0}$ \\
\hline
\end{tabular}

Table 8 shows that majority of the respondents (95 or $48.2 \%$ ) believe that media groups undertake minimal activities to promote environmental health education and standards at Onitsha Urban. This finding implies that government efforts are largely not complemented by media outfits.

Table9. Respondents assessment of media role in environmental health education at Onitsha Urban?

\begin{tabular}{|c|c|c|}
\hline Responses & Frequency & Percent \\
\hline Outstandingly effective & 25 & 13.3 \\
\hline Very effective & 71 & 36.4 \\
\hline Minimally effective & 96 & 49.2 \\
\hline Not effective & 2 & 1.0 \\
\hline I don't know & 2 & 1.0 \\
\hline Total & 195 & 100.0 \\
\hline
\end{tabular}

Table 9 shows that $96(42.2 \%)$ of the respondents believe that media role in environmental health education of residents of Onitsha is minimally effective.

\subsection{Research Question 6:}

What are the perceived obstacles confronting media institutions in discharging environmental health education roles in Onitsha Urban, Anambra state of Nigeria? The findings are presented on Table 10.

Table10. Distribution of Respondents by their opinion on obstacles affecting media role in environmental health education and standards maintenance at Onitsha Urban.

\begin{tabular}{|l|c|c|}
\hline Responses & Frequency & Percent \\
\hline Lack of fund & 25 & 12.3 \\
\hline Lack of interest & 69 & 34.4 \\
\hline Media partnership was not solicited by government & 96 & 49.2 \\
\hline Their staff lack relevant capacity & 3 & 2.0 \\
\hline I don't know & 3 & 3.0 \\
\hline Total & $\mathbf{1 9 5}$ & $\mathbf{1 0 0 . 0}$ \\
\hline
\end{tabular}

Table 10 shows that most respondents felt that media role in environmental health education is affected by failure of government to solicit their co-operation in that regard.

\subsection{Research Question 7:}

What measures should be put in place to step up media roles and ensure safe environmental health standards at Onitsha Urban in Anambra State? The findings are shown in table 11.

Table11. Distribution of Respondents by their opinion on the most important measure that will scale up media roles and ensure safe environmental health standards at Onitsha Urban in Anambra State

\begin{tabular}{|c|c|c|}
\hline Responses & Frequency & \begin{tabular}{|l|} 
Percent \\
\end{tabular} \\
\hline Government to provide grants to media stations for environmental health education activities & 2 & 1.0 \\
\hline All media stations to be mandated to devote time for environmental health education & 2 & 1.0 \\
\hline $\begin{array}{l}\text { More documentaries should be created by media houses in the area of environmental health } \\
\text { education }\end{array}$ & 1 & .5 \\
\hline $\begin{array}{l}\text { All media outfits must broadcast/publish three adverts and jingles in the area of environmental } \\
\text { health education per day }\end{array}$ & 2 & 1.0 \\
\hline All of the above & 188 & 96.4 \\
\hline Total & 195 & $\mathbf{1 0 0 . 0}$ \\
\hline
\end{tabular}


Table11 shows that majority of the respondents (96.4\%) considered all the listed measures as important for improving media roles in environmental health education and standards maintenance at Onitsha Urban.

\section{TEST OF STUDy HyPOTHESIS}

The researcher tested the two hypotheses postulated for this study. The details are as follows:

\subsection{Hypothesis 1}

"There is a significant relationship between one's level of educational attainment of Onitsha Urban Residents and their perception of major environmental health challenges of the area'".

Data in tables 12 and 13 formed the basis for testing hypothesis. Test results are shown on Table 18 below.

Table12. Relationship (association) between level of education and perception of major environmental health problems in Onitsha North Local Government Area.

\begin{tabular}{|c|c|c|c|c|c|c|}
\hline $\begin{array}{l}\text { What is the level of } \\
\text { education you have }\end{array}$ & $\begin{array}{l}\text { Which of these } \\
\text { Onitsha Urban? }\end{array}$ & a major env & onmen & health challenge face & by res & \\
\hline attained & Water pollution & Air pollution & Noise & Refuse Accumulation & Total & $\Leftrightarrow$ \\
\hline No formal education & 1 & 1 & 1 & 1 & 4 & $\infty$ \\
\hline FSLC & 1 & 1 & 1 & 2 & 5 & $\dot{q}$ \\
\hline SSCE & 10 & 6 & 21 & 15 & 52 & $=\overline{8}$ \\
\hline B.Sc. & 4 & 11 & 27 & 70 & 112 & no. \\
\hline Ph.D. & 1 & 1 & 3 & 8 & 13 & II 2 \\
\hline NCE & 1 & 1 & 2 & 1 & 5 & $\infty$ \\
\hline M.Sc. & 1 & 1 & 1 & 1 & 4 & $=$ \\
\hline Total & 19 & 22 & 56 & 98 & 195 & $x$ \\
\hline
\end{tabular}

The computed value of Chi-square is 43.861 while the table value of chi-square at 0.05 level of significance with a degree of freedom (df) of 18 is 28.869 . Since the computed chi square value is greater than the critical value, the researcher accepted the alternative hypothesis. It follows therefore that there is a significant relationship between level of educational attainment and perception of environmental health problems in Onitsha Urban.

Table12.Logistic Regression Predicting the Influence of Socio-Demographic Variables on 'Disposition to Environmental Health Responsibilities'.

\begin{tabular}{|l|l|l|l|l|l|l|}
\hline & B & S.E. & Wald & Df & Sig. & Exp(B) \\
\hline Age & -.672 & .071 & 88.569 & 1 & .000 & .521 \\
\hline Sex & -.352 & .165 & 4.577 & 1 & .031 & 1.424 \\
\hline Religion & -.536 & .136 & 15.562 & 1 & .000 & .583 \\
\hline Education & .340 & .067 & 25.453 & 1 & .000 & 1.405 \\
\hline Occupation & .076 & .044 & 3.053 & 1 & .082 & 1.078 \\
\hline Constant & 1.066 & .473 & 5.085 & 1 & .024 & 2.905 \\
\hline
\end{tabular}

According to the distribution in the table, three variables, age, religion, and education were statistically very significant $(\mathrm{p}<0.000)$. The exponential of the distribution shows that older respondents are more likely to be positively disposed to environmental health responsibilities than younger ones. Also, those with higher education are $140 \%$ more likely to be positively disposed than those with lower level of education. Therefore age and education are good predicators on disposition to environmental health responsibilities with education being the best predicator.

\section{DisCuSSION OF FINDINGS/ CONCLUSIONS}

The study found that refuse accumulation was considered by residents to be the major environmental health problem encountered in Onitsha Urban Area. This finding agrees with Mogbo (2004) and Agu (2004) cited in Nwankwo (2006). In their categorization of environmental health problems at urban towns in Nigeria, these scholars grouped the problems into primary and secondary. They defined secondary environmental health problems as the effects of economic development. Hence, refuse accumulation, air, water and land pollution experienced at Onitsha are occasioned by industrialization and urbanization. Indeed, refuse dumps arise from human errors. 
This study also found that the people are not adequately informed, aware or enlightened about environmental health issues. Majority of respondents attest that they have not benefited from knowledge update seminars on environmental health. This obviously contributes to their poor response or intervention to environmental health problems. Ignorance about environmental health related matters which were also applicable to children in schools (Udoh, 1998) thus constitute a major factor that gave rise to the problems. It also accounted for the people's mismanagement of the environment because they were not aware of its outrageous effects on them. Above all, the low level of awareness aptly justifies the view of $96.4 \%$ of the respondents that the media should be involved to raise environmental health awareness and consciousness of the people.

Unfortunately, the study also found that meria groups were not participating fully in environmental health education and related matters. The study further observed that residents assessed the role of the media in environmental health education as minimally effective. This implies that they felt that efforts media outfits in that regards were not enough. There is certainly immense need for stepping up such efforts.

Finally, the adequacy of the theoretical framework adopted for this study is not in doubt. The human ecological theory with its emphasis on interrelationships between people and their environment is totally in tune with the findings of this study. The study has successfully linked indiscriminate dumping of refuse on the environment by residents of Onitsha Urban to the environmental health challenges of the area.

\section{RECOMMENDATIONS}

In view of the finding that media involvement in environmental health education at Onitsha Urban is low with very limited results over the years, the researcher therefore recommends the following:

- Effective public enlightenment campaign programmes should be mounted through the mass media and other arrangements. These programmes are to be held at strategic points like market places, and as part of sermons by religious leaders. Musical artists should also be involved to deliver environmental health messages through their music. This is to awaken public concern over environmental health problems and to propagate high ethics on how to manage both domestic and industrial wastes.

- All media stations to be mandated to devote time for environmental health education of the populace, not less than one hour each day

- More documentaries should be created by media houses in the area of environmental health education of the populace

- Government to provide grants to media stations for environmental health education of the populace

\section{REFERENCES}

[1] Babanyara,Y.Y., Usman, H.A. and Saleh, U.F.(2010). An Overview of Urban Poverty and Environmental Problems in Nigeria. Bauchi: Urban and Regional Planning Programs, Abubakar Tafawa Balewa University, Bauchi, Nigeria.

[2] Bosah, S.I. (2000). Groundwork of the History and Culture of Onitsha. Onitsha: OJ Press

[3] Centre For Public Health, Faculty of Health and Applied Social Sciences, University of Liverpool (2009). Health Risk Perception and Environmental Problems. Accessed on 24/1/2012 through www.cph.org.uk/publications.

[4] Crawford, M. (2001). Air Pollution Control Theory, USA: McGraw Hill Book Company.

[5] Dike, A.A. (1985). Environmental Problems of Third World Cities: A Nigerian Example. Current Anthropological Journal, 26/4, August-October, pg i5-21

[6] Environmental Health Officers Association of Nigeria (EHOAN, 2007). Communiqué of her 2007 National Delegates Conference/Scientific Workshop held at Kano, 26 ${ }^{\text {th }}$ Feb. $-3^{\text {rd }}$ March.

[7] Erinosho O.A \&Oke E.A (2004). Some Basic Concepts in Medical Sociologand Anthropology, in Otite .O. (ed), Sociology: Theory and Applied, Lagos: Malthouse Press Ltd, pg 71-80

[8] Metiboba, S., Nigeria's National Health Insurance Scheme: The Need for Beneficiary Participation. Research Journal of International Studies, 4/2, Nigeria: Euro Journals Publishing, Inc, 2011. 
[9] Mogbo C.K (2004). Environmental Sanitation for Sustainable Development in the new Millennium. Being Paper Presented at a 3-Day Seminar Organized at Awka by Environmental Health Officers Association of Nigeria, Anambra State Chapter, 10-12 ${ }^{\text {th }}$ Nov

[10] Mooney, L.A., Knox, D., \& Schacht, C. (2000) Understanding Social Problems (2 ${ }^{\text {nd }}$ ed.), Cincinnati, OH: Wadsworth,. Pg 10-16.

[11] Nnatu, S.O. (2010). Lecture Mimeograph on Urban Sociology, Nnamdi Azikiwe University Awka.

[12] Nwankwo, I.U. (2006). Towards Improved Environmental Health Management In Anambra State: Harnessing The Socio-Cultural Attributes Of The State To Advantage. Proceedings of $3^{\text {rd }}$ SOSEH National Conference, Awka 2006.

[13] Nwankwo, I.U. (2014).Public Perception of Environmental Health Problems in Onitsha North LGA of Anambra State, in Au Nnonyelu and Makodi Bierenu-Nnabugwu (eds), Themes and Perspectives of the Social Sciences in Africa, 2/1, pp78-112

[14] Nzeadibe, T.C. and Ajaero, C.K. (2008). Introducing Nigerian Undergraduates to the Formal and Informal Sectors. Waste management \& Recycling Research Unit, Department of Geography, University of Nigeria, Nsukka, Nigeria.

[15] Obianyo P. (2004). An Address of Welcome to the Opening Ceremony of a 3-Day Seminar Organized at Awka by the Environmental Health Officers Association of Nigeria, Anambra State Chapter,10-12 ${ }^{\text {th }}$ Nov.

[16] Obionu C. N. (2011).Sustainable Healthy Environment: A Challenge to the Nigerian State. International Journal of Health and Social Inquiry, 1/1,pg 21-26

[17] Okafor G.O, Nwankwo I.U., Oli N.P,and Oguamanam G.O (2016). Health Information Dissemination in an Era of Globalization among the Igbo of Southeast Nigeria: Harvesting Resilient Traditional Media Systems to Advantage, Advances in Research,7/4, ppl-7

[18] Udoh, C.O. (1998). Special Environmental Health Problems in Rural Schools in Nigeria. Nigerian School Health Journal.3, pg 17-23

[19] UN Habitat (2009) cited http//: www.google.com accessed 14/12/11

[20] World Health Organization (WHO, 1992). On Being in Charge: A Guide to Management in Primary Health Care, Geneva

[21] World Health Organisation (2006). Health Promotion in Developing Countries. Briefing book to the Sundsvall Conference on Supportive Environment, Geneva. 